\title{
PENGARUH GOOD CORPORATE GOVERNANCE TERHADAP KINERJA SAHAM PERUSAHAAN \\ (Studi Empiris pada Saham LQ 45 di BEI)
}

\author{
Oleh : Abdul Karim, SE.,M.Si.
}

Fakultas Ekonomi

Universitas Semarang

\begin{abstract}
Abstrak
Corporate governance telah menjadi topik yang menarik untuk diteliti pada saat sekarang ini. Hal ini karena meningkatnya kebutuhan untuk menerapkan good corporate governance yang disuarakan secara global didorong oleh terjadinya skandal yang terjadi di Enron, Worldcom, Parmalat untuk perusahaan yang ada di Amerika serta PT. Agis sebagai contoh perusahaan di Indonesia yang disebabkan oleh kurangnya penerapan corporate governance yang baik. Skandal - skandal akuntansi tersebut tentunya akan berdampak terhadap ekonomi suatu bangsa melalui efeknya terhadap pasar modal.

Penelitian ini mempunyai tujuan untuk menganalisis pengaruh komisaris independent, kepemilikan manajerial, kepemilikan asing, hutang, serta kualitas audit terhadap kinerja saham perusahaan yang termasuk dalam LQ 45 di Bursa Efek Indonesia tahun 2006 - 2008 dan untuk memberikan gambaran bagaimana penerapan good corporate governance yang berkembang pada perekonomian seperti sekarang ini.

Berdasarkan hasil analisis dan pengujian, data menunjukkan tidak adanya pengaruh yang signifikan antara komisaris independent (INED) terhadap kinerja perusahaan, hal ini membuktikan bahwa tidak adanya pengaruh komisaris independent terhadap kinerja saham. Kemudian adanya pengaruh positif antara kepemilikan manajerial terhadap kinerja perusahaan, yang berarti bahwa semakin besar jumlah kepemilikan manajerial akan meningkatkan nilai perusahaan. Kemudian terdapat pengaruh positif signifikan antara kepemilikan asing terhadap kinerja perusahaan. Hal ini mengindikasikan bahwa para investor di Bursa Efek Indonesia ternyata juga memperhatikan jumlah kepemilikan asing dalam menilai suatu perusahaan. Kemudian analisis data menunjukkan bahwa terdapat pengaruh positif signifikan antara hutang dengan nilai perusahaan. Hal ini juga mengindikasikan bahwa para investor di Bursa Efek Indonesia memperhatikan pengawas lain akan suatu perusahaan.

Hasil analisis data menunjukkan bahwa terdapat pengaruh positif signifikan antara kualitas audit dengan nilai perusahaan. Hal ini mengindikasikan bahwa kualitas audit yang digambarkan dengan kantor akuntan yang termasuk big 4 akan berpengaruh terhadap nilai suatu perusahaan. Kualitas audit biasanya mempengaruhi luasnya suatu pemeriksaan sehingga kredibilitas hasil audit bisa diandalkan.
\end{abstract}

Keywords : GCG, komisaris independen, kepemilikan manajerial, kepemilikan asing, kualitas audit 


\section{PENDAHULUAN}

\section{Latar Belakang Masalah}

Corporate governance telah menjadi topik yang menarik untuk diteliti pada saat sekarang ini. Hal ini karena meningkatnya kebutuhan untuk menerapkan good corporate governance yang disuarakan secara global. Keadaan tersebut didorong oleh terjadinya skandal yang terjadi di Enron, Worldcom, Parmalat untuk perusahaan yang ada di Amerika serta PT. Agis sebagai contoh perusahaan di Indonesia yang disebabkan oleh kurangnya penerapan corporate governance yang baik. Skandal - skandal akuntansi tersebut tentunya akan berdampak terhadap ekonomi suatu bangsa melalui efeknya terhadap pasar modal.

Wolfhenson, 1999 menyatakan bahwa corporate governance yang buruk juga disebutkan sebagai salah satu penyebab dari krisis ekonomi yang terjadi di Asia Timur pada tahun 1997-1998, termasuk di Indonesia. Ciri utama dari corporate governance yang buruk adalah adanya tindakan dari manajer perusahaan yang mementingkan dirinya sendiri sehingga mengabaikan kepentingan investor, dimana ini akan menyebabkan jatuhnya harapan para investor tentang return atas investasi yang mereka harapkan menurut Darmawati, Deni, Khomsiyah, Rika Gelar R. (2004).

Terdapat lima pilar dalam prinsipprinsip corporate governance yang dikemukakan oleh OECD adalah fairness (keadilan), transparancy (transparansi), accountability (akuntabilitas), responsibility (pertanggungjawaban), dan independency (independensi). Pilar-pilar inilah yang melandasi prinsip-prinsip corporate governance menurut $\mathrm{OECD}$ yaitu hak-hak pemegang saham, perlakuan yang adil kepada pemegang saham, peranan stakeholders dalam corporate governance, pengungkapan dan transparansi, serta tanggung jawab dewan direksi.

Prinsip-prinsip di atas ditujukan untuk mewujudkan good corporate governance (GCG) yang merupakan sistem yang mengatur dan mengendalikan perusahaan untuk menciptakan nilai tambah (value added) bagi semua stakeholders, menekankan pentingnya hak pemegang saham untuk memperoleh informasi dengan benar, akurat, dan tepat waktu serta kewajiban perusahaan untuk mengungkapkan (disclosure) secara akurat, tepat waktu dan transparan mengenai semua informasi kinerja perusahaan, kepemilikan dan stakeholders (YPPMI \& SC, 2002 dalam Sulistiyanto dan Prapti, 2003).

Bukti empiris mengenai kepemilikan manajerial dengan kinerja perusahaan juga belum jelas. Penelitian yang dilakukan Himmelberg et al., (1999) tidak menemukan korelasi yang bermakna antara kepemilikan manajerial dengan kinerja. Namun , Khanna A., Mahentiran, S., and Curci, R. (2005) menemukan bukti yang kuat bahwa kepemilikan manajerial mempengaruhi nilai perusahaan.

Kepemilikan asing diduga menjadi salah satu cara untuk meng-upgrade perusahaan - perusahaan secara teknologi di negara - negara berkembang, melalui impor langsung modal baru dan teknologi baru menurut Benfratello dan Sembenelli, (2002). Kozlov et al. (2000) menunjukkan bahwa perusahaan - perusahaan asing diketahui lebih produktif dibandingkan perusahaan domestik. Makhija dan Spiro, (2000) meneliti harga saham 988 perusahaan Czech yang baru diprivatisasi dan menemukan bahwa harga saham tersebut berkorelasi positif dengan kepemilikan asng. Hasil yang serupa juga dilaporkan oleh Hingorani et al, (1997) yang menyimpulkan bahwa insider ownership dan kepemilikan asing mengurangi masalah - masalah keagenan 
melalui insentif - insentif yang menyelaraskan kepentingan para manajer dan investor.

Di Indonesia peneliti belum menemukan bukti empiris tentang pengaruh kepemilikan asing terhadap kinerja perusahaan. Meski demikian, diduga bahwa kepemilikan asing memiliki dampak tidak langsung terhadap corporate governance, sehubungan dengan adanya perusahaan - perusahaan milik asing yang akan meningkatkan persaingan di pasar.

Penelitian ini mencoba memperjelas obyek yaitu saham LQ 45 tahun 2006 - 2008, karena penelitian yang dilakukan oleh Che Hat et al., (2008) adalah seluruh saham yang listed KLSE Malaysia. Hal tersebut kurang sesuai, karena tidak semua saham yang listed di bursa efek tersebut likuid, sehingga untuk mengukur kinerja saham perusahaan kurang bagus. Untuk itu dalam penelitian ini mencoba hanya memasukkan saham saham likuid yang termasuk dalam LQ 45 di Bursa Efek Indonesia (BEI).

Dalam penelitian ini hanya memasukan 5 (lima) karakteristik good corporate governance yaitu komposisi komisaris independen, kepemilikan manajerial, kepemilikan asing, hutang serta kualitas audit, karena kelima karakteristik tersebut telah mewakili tentang mekanisme good corporate governance, baik dari aspek internal, aspek kepemilikan dan aspek keuangan. Penelitian ini diklasifikasikan dalam tiga aspek yaitu (1) mekanisme internal (komisaris independent dan kualitas audit), (2) kepemilikan (kepemilikan manajerial, kepemilikan asing) dan (3) keuangan (hutang).

\section{Perumusan Masalah}

Berdasarkan latar belakang masalah yang telah diuraikan di atas, serta belum konsistennya beberapa penelitian dalam menghubungkan antar variabel, maka rumusan masalah dalam penelitian ini adalah bagaimana pengaruh komisaris independen, kepemilikan manajerial, kepemilikan asing, hutang, serta fee audit terhadap kinerja saham perusahaan?

\section{Tujuan Penelitian}

Sesuai dengan rumusan masalah di atas, penelitian ini mempunyai tujuan sebagai berikut :

1. Untuk menganalisis pengaruh komisaris independent, kepemilikan manajerial, kepemilikan asing, hutang, serta kualitas audit terhadap kinerja saham perusahaan yang termasuk dalam LQ 45 di Bursa Efek Indonesia tahun 2006 - 2008.

2. Untuk memberikan gambaran bagaimana penerapan good corporate governance yang berkembang pada perekonomian seperti sekarang ini.

\section{TELAAH TEORI}

\section{Agency Theory (Teori agensi)}

Dalam konsep agency theory, manajemen sebagai agen semestinya menjunjung tinggi kepentingan shareholders, akan tetapi tidak tertutup kemungkinan manajemen hanya mementingkan kepentingannya sendiri untuk memaksimalkan utilitas. Perbedaan kepentingan antara pemilik dan pengelola inilah yang disebut agency problem.

Adanya asymetric information dan sikap mementingkan diri sendiri pada manajer/agen, menimbulkan tata kelola perusahaan yang kurang sehat karena tidak adanya keterbukaan dari manajemen untuk mengungkapkan hasil kinerjanya kepada pemilik perusahaan (Arifin, 2005).

Berdasarkan keadaan tersebut, dibutuhkan sistem tata kelola perusahaan yang baik pada perusahaan (good corporate governance) yang bertujuan untuk mendorong pengelolaan corporate yang terbuka dan accountable sehingga pemegang saham mempunyai kesempatan untuk mengkaji berbagai keputusan dan dasar pengambilan keputusan tersebut, serta menilai keefektifan keputusan yang telah diambil oleh manajemen (Riyanto, 2005).

Signalling Theory (Teori sinyal) 
Menurut Moris (1987) asumsi dasar signaling theory adalah masalah asimetri informasi yang terjadi dalam pasar. Teori ini menunjukkan bagaimana asimetri informasi dapat dikurangi oleh pihak yang lebih banyak memiliki informasi dengan mengirimkan sinyal kepada pihak lain. Signaling merupakan suatu gejala umum yang dapat diaplikasikan pada setiap pasar dengan asimetri informasi.

Signaling theory juga menjelaskan kaitan sebuah industri, bahwa setiap deviasi dari praktik pelaporan keuangan perusahaan mungkin akan dilihat oleh pasar sebagai bad news (Giner, 1997).

\section{Pengertian Good Corporate Govenance}

Komite Cadburry (1992) melalui apa yang dikenal dengan sebutan Cadburry Report mengeluarkan definisi tersendiri tentang GCG :

"GCG adalah prinsip yang mengarahkan dan mengendalikan perusahaan agar mencapai keseimbangan antara kekuatan serta kewenangan perusahaan dalam memberikan pertanggungjawabannya kepada para shareholders khususnya, dan stakeholders pada umumnya."

Organization for Economic Coorperation and Development (2004) mendefinisikan:

"GCG adalah cara - cara manajemen perusahaan bertanggungjawab pada sharehoider-nya. Para pengambil keputusan di perusahaan haruslah dapat dipertanggungjawabkan, dan keputusan tersebut mampu memberikan nilai tambah bagi shareholders lainnya."

GCG di Indonesia didefinisikan sebagai suatu pola hubungan, sistem, dan proses yang digunakan oleh organ perusahaan (Board of Director (BOD), Rapat Umum Pemegang Saham (RUPS) guna memberikan nilai tambah kepada Pemegang Saham secara berkesinambungan dalam jangka panjang, dengan tetap memperhatikan kepentingan stakeholders lainnya, berlandaskan peraturan perundangan dan norma yang berlaku.

\section{Mekanisme Corporate Governance}

Walsh dan Seward (1990) menyatakan bahwa terdapat 2 mekanisme untuk membantu menyamakan perbedaan kepentingan antara pemegang saham dan manajer dalam rangka penerapan Corporate Governance, yaitu :

1. Mekanisme pengendalian internal perusahaan yaitu pengendalian yang dilakukan dengan membuat seperangkat aturan yang mengatur tentang mekanisme bagi hasil, baik yang berupa keuntungan, return maupun resiko yang disetujui oleh principal dan agen.

2. Mekanisme pengendalian ekternal berdasarkan pasar adalah pengendalian perusahaan yang dilakukan oleh pasar. Menurut teori pasar untuk pengendalian perusahaan (market for corporet controll), pada saat diketahui bahwa manajemen berperilaku menguntungkan diri sendiri kinerja perusahaan akan menurun yang direfleksikan oleh nilai saham perusahaan.

\section{Kerangka Konseptual}

Berdasarkan telaah teoritis serta penelitian terdahulu di atas menunjukkan adanya hubungan komposisi komisaris, direksi, kepemilikan serta kualitas audit terhadap kinerja saham perusahaan. Penelitian yang telah menemukan bahwa memiliki lebih banyak direktur independen luar pada dewan (INDEP) meningkatkan kinerja Daily dan Dalton, (1994). Hingorani et al., (1997), menyimpulkan bahwa insider ownership dan kepemilikan asing (FOREIGN) mengurangi masalahmasalah keagenan melalui insentif-insentif yang menyelaraskan kepentingan para manajer dan investor. Penelitian yang dilakukan oleh Harvey et al., 2003, 
menyatakan bahwa biaya keagenan dapat diatasi dengan cara manajemen menunjukkan kemauan mereka untuk diawasi oleh para kreditur seperti bank dengan meningkatkan pinjamannya.

Berdasarkan uraian diatas, dapat dibuat model penelitian sebagai berikut :

Gambar 1 Model Hubungan Antara Mekanisme Good Corporate Governance (Komisaris Independen, Kepemilikan Manajerial, Kepemilikan Asing, Hutang dan Kualitas Audit) dengan Kinerja Saham

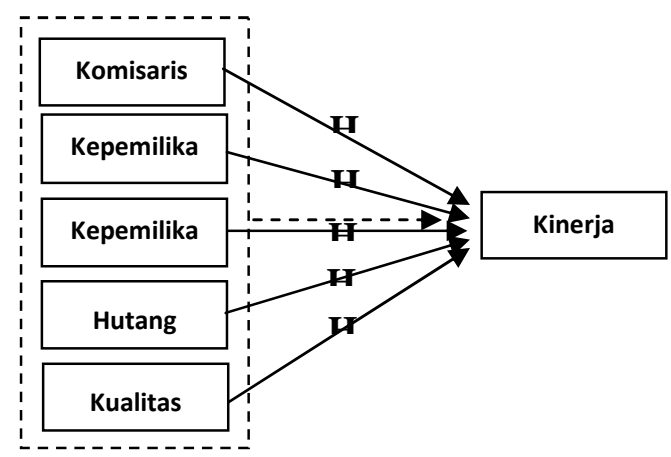

Hipotesis

H1 : Komposisi komisaris independen berpengaruh secara positif terhadap kinerja saham perusahaan.

$\mathrm{H} 2$ : Kepemilikan manajemen berpengaruh positif terhadap kinerja saham perusahaan

H3 : Kepemilikan Asing berpengaruh positif terhadap kinerja saham perusahaan

H4 : Hutang berpengaruh positif terhadap kinerja saham perusahaan

H5 : Kualitas audit berpengaruh positif terhadap kinerja saham perusahaan

\section{METODE PENELITIAN}

\section{Data Penelitian}

Data dalam penelitian ini adalah seluruh populasi perusahaan yang termasuk dalam perusahaan LQ-45 yang terdaftar di Bursa Efek Indonesia (BEI) dan telah mempublikasikan laporan keuangannya tahun 2006 - 2008. Penelitian ini hanya memakai data saham yang termasuk LQ - 45 karena dianggap merupakan saham yang likuid dan bukan saham yang bersifat pasif, sehingga akan lebih tepat untuk mengukur kinerja saham perusahaan.

\section{Variabel Penelitian dan Definisi Operasional \\ 1.Variabel Dependen}

Variabel dependen dalam penelitian ini adalah nilai perusahaan yang digambarkan dengan Tobin's Q sebagai proksi dari kinerja perusahaan dari harga sahamnya. Tobin's $Q$ ditemukan oleh seorang pemenang nobel di Amerika Serikat yaitu James Tobin (Agustin, 2007:18). Rasio Tobin's $Q$ didevinisikan sebagai nilai pasar dari ekuitas ditambah dengan total kewajiban dan kemudian dibagi dengan total aktivanya (Chong dan Lopez-de-Silanes 2006 dalam Kusumastuti et al. 2005:93). Rasio Tobin's $Q$ dirumuskan sebagai berikut :

TOBIN $=(\mathrm{MVE}+\mathrm{DEBT}) / \mathrm{TA}$

$\mathrm{MVE}=\mathrm{P} \times \mathrm{Qshar}$

$\mathrm{DEBT}=(\mathrm{CL}-\mathrm{CA})+\mathrm{INV}+\mathrm{LT}$

Dimana :

MVE : Nilai pasar dari lembar saham beredar DEBT: Nilai total kewajiban perusahaan

TA : Nilai buku dari total aktiva perusahaan P : Harga saham penutupan akhir tahun Qshares: Jumlah saham beredar akhir tahun

CL : Kewajiban jangka pendek

CA : Aktiva Lancar

INV : Nilai buku persediaan

LTL : Kewajiban jangka panjang

Semakin besar nilai rasio tobin's $Q$ menunjukkan bahwa perusahaan memiliki prospek pertumbuhan yang baik dan memiliki intangible asset yang semakin besar. Hal ini bisa terjadi karena semakin besar nilai pasar asset suatu perusahaan, semakin besar kerelaan investor untuk mengeluarkan pengorbanan yang lebih untuk memiliki perusahaan tersebut. Sedangkan nilai rasio tobin's $Q$ yang rendah menunjukkan bahwa perusahaan tersebut memiliki nilai pasar yang lebih rendah dibandingkan nilai aktivanya.

\section{Variabel Independen}

1. Komposisi Komisaris Independen 
Komposisi komisaris independen (INED) adalah proporsi dari komisaris independen terhadap total komisaris dalam suatu perusahaan menurut Che Hat et al., (2008).

2. Kepemilikan manajerial (INSIDER) adalah prosentase saham yang dimiliki oleh manajemen atau direksi terhadap total saham perusahaan, menurut Che Hat et al., (2008).

3. Kepemilikan asing (FOREIGN) adalah prosentase saham yang dimiliki oleh orang luar negeri terhadap total saham perusahaan, menurut Che Hat et al., (2008).

4. Hutang (DEBT) adalah hasil dari hutang jangka panjang dibagi dengan total aset, sesuai dengan penelitiannya Che Hat et al., (2008)

5. Kualitas Audit (AUDIT) adalah proksi dari kantor akuntan yang mengaudit perusahaan data, jika termasuk big four maka mendapat angka 1 dan jika bukan big four maka mendapat angka 0 seperti yang dilakukan oleh Francis dan Simon, (1987)

\section{METODE ANALISIS}

Sampel penelitian adalah perusahaan LQ 45 yang mengeluarkan laporan keuangan pada tahun 2006 - 2008. Berdasarkan spesifikasi data yang diamati sebelumnya, secara rinci jumlah perusahaan LQ 45 yang terdaftar di BEJ pada tahun 2006- 2008 dan memiliki data yang lengkap untuk pengukuran variabel penelitian secara kumulatif berjumlah 120 perusahaan. Perincian dari sampel penelitian adalah sebagai berikut :

Tabel 1

Perincian pemilihan sampel

\begin{tabular}{|l|c|c|c|}
\hline & 2006 & 2007 & 2008 \\
\hline $\begin{array}{l}\text { Perusahaan LQ 45 yang } \\
\text { terdaftar di BEJ selama } \\
\text { tahun 2006 - 2008 }\end{array}$ & 45 & 45 & 45 \\
\hline $\begin{array}{l}\text { Perusahaan perbankan } \\
\text { dan lembaga keuangan }\end{array}$ & 4 & 4 & 4 \\
\hline
\end{tabular}

\begin{tabular}{|l|c|c|c|}
\hline Perusahaan & 40 & 41 & 39 \\
\hline Total Sampel & \multicolumn{3}{|c|}{120} \\
\hline
\end{tabular}

Sumber : Data sekunder yang diolah 2009

Sebelum membahas terhadap pembuktian hipotesis, secara deskriptif akan dijelaskan mengenai kondisi masingmasing variabel yang digunakan dalam penelitian ini.

\section{Analisis Deskriptif}

Analisis deskriptif dari data yang diambil untuk penelitian ini adalah dari tahun 2006 hingga tahun 2008 untuk masing-masing variabel terdapat pada Tabel berikut :

Tabel 2

Deskripsi variabel Penelitian Perusahaan Sampel

\begin{tabular}{|l|c|c|r|r|r|}
\hline & $\mathrm{N}$ & \multicolumn{1}{c|}{ Min } & \multicolumn{1}{c|}{ Max } & \multicolumn{1}{c|}{ Mean } & $\begin{array}{c}\text { Std. } \\
\text { Deviation }\end{array}$ \\
\hline INED & 120 & .0000 & .7500 & .3625 & .1733 \\
INSIDER & 120 & .0000 & 28.7576 & .9061 & 3.7859 \\
FOREIGN & 120 & .0000 & 89.0799 & 23.228 & 25.3033 \\
DEBT & 120 & .0018 & .6858 & .2509 & .1958 \\
TOBINS Q & 120 & .3347 & 10.1514 & 1.9284 & 1.5485 \\
Valid N & 120 & & & & \\
(listwise) & & & & \\
\hline
\end{tabular}

$(\mathrm{n}=120) \quad$ Sumber : Data sekunder yang diolah

Namun demikian pada jumlah tersebut, dalam pengujian regresi masih belum memenuhi asumsi noramalitas data. Dengan demikian sejumlah data dikeluarkan karena dinilai sebagai outlier. Diskripsi data setelah mengeluaran beberapa data outlier diperoleh sebagai berikut :

Tabel 3.

Deskripsi variabel Penelitian Perusahaan Sampel setelah mengeluarkan outlier $(\mathrm{n}=110)$

\begin{tabular}{|l|l|l|r|r|r|}
\hline & $\mathrm{N}$ & \multicolumn{1}{|c|}{ Min } & \multicolumn{1}{c|}{ Max } & \multicolumn{1}{c|}{ Mean } & \multicolumn{1}{c|}{$\begin{array}{c}\text { Std. } \\
\text { Deviation }\end{array}$} \\
\hline INED & 110 & .0000 & .7500 & .3671 & .1731 \\
INSIDER & 110 & .0000 & 28.7576 & .7963 & 3.4519 \\
FOREIGN & 110 & .0000 & 89.0799 & 23.0475 & 24.1284 \\
DEBT & 110 & .0018 & .6858 & .2547 & .1943 \\
TOBINS & 110 & .3347 & 3.6964 & 1.5488 & .7434 \\
Q & & & & & \\
$\begin{array}{l}\text { Valid N } \\
\text { (listwise) }\end{array}$ & 110 & & & & \\
\hline
\end{tabular}




\section{Coefficients}

\begin{tabular}{|c|c|c|c|c|c|c|c|c|}
\hline \multirow[b]{2}{*}{ Mods } & & \multicolumn{2}{|c|}{$\begin{array}{r}\text { Unstandard } \\
\text { Coefficient }\end{array}$} & \multirow{2}{*}{$\begin{array}{c}\text { Standaro } \\
\text { Coefficie } \\
\text { Beta }\end{array}$} & \multirow[b]{2}{*}{$\mathrm{t}$} & \multirow[b]{2}{*}{ Sig. } & \multicolumn{2}{|c|}{ Collinearity St } \\
\hline & & B & Std. E & & & & Tolera & VIF \\
\hline 1 & (Consta & 1.2 & .20 & & 6.08 & .00 & & \\
\hline & INED & -.70 & .38 & -.16 & -1.8 & .06 & .94 & 1.05 \\
\hline & INSIDE & -.02 & .01 & $-.0 \$$ & -1.0 & .30 & .93 & 1.0 \\
\hline & FOREIC & .00 & .00 & .20 & 2.36 & .02 & .96 & 1.04 \\
\hline & DEBT & .66 & .33 & .17 & 1.99 & .04 & .96 & 1.03 \\
\hline & AUDIT & .46 & .13 & .31 & 3.5 & .00 & .96 & 1.04 \\
\hline
\end{tabular}

Nilai perusahaan yang diukur dengan menggunakan Tobins $\mathrm{Q}$ diperoleh rata-rata sebesar 1,5488. Nilai rata-rat Tobins Q di atas 1 menunjukkan bahwa nilai pasar perusahaan lebih tinggi dibanding dengan nilai bukunya. Hal ini menunjukkan pula bahwa perusahaan sedang menglami pertumbuhan. Nilai Tobins Q terendah adalah sebesar 0,3347 dan nilai tertinggi adalah 3,6964.

Nilai rata-rata proporsi komisaris independen yang diukur dengan proporsi jumlah komisaris independen dibanding dengan jumlah total dewan komisaris diperoleh rata-rata sebesar 0,3671 . Hal ini berarti bahwa secara rata-rata perusahaan sampel mencapai 0,3671 atau $36,71 \%$. Proporsi komisaris independen terendah adalah sebesar $0 \%$ dan yang paling banyak mencapai 0,7500 atau $75,00 \%$.

Nilai rata-rata variabel INSIDER diperoleh sebesar 0,7963. Hal ini berarti bahwa rata-rata perusahaan sampel memiliki $0,7963 \%$ saham perusahaan dimiliki oleh jajaran manajemen yaitu direktor maupun komisaris perusahaan. Kepemilikan saham oleh manajerial dimungkinkan dapat memperkecil masalah keagenan yang mungkin muncul dan berkembang antara kepentingan agen dan principal. Nilai terkecil dari variabel insider diperoleh sebesar 0,000 sedangkan nilai maksimal adalah 18.7576 persen.

Nilai rata-rata variabel kepemilikan asing (FOREIGN) diperoleh sebesar 23,0475. Hal ini berarti bahwa rata-rata perusahaan sampel memiliki 23,0475 persen saham perusahaan dimiliki oleh perusahaan atau perseorangan asing. Kepemilikan saham oleh asing dapat diperkenankan oleh otoritas penanaman modal. Nilai terkecil dari variabel kepemilikan saham asing adalah sebesar 0,000 sedangkan nilai maksimal adalah 89,0799 persen atau terdapat kepemilikan saham asing yang lebih besar dari total saham.

Debt ratio yang menunjukkan struktur hutang jangka panjang terhadap total aset yang pada pada perusahaan sampel menunjukkan bahwa rata-rata debt ratio mencapai 0,2547. Hal ini berarti bahwa $25,47 \%$ aset yang dipergunakan oleh perusahaan sampel berasal dari hutang jangka panjang perusahaan debt ratio terendah adalah sebesar 0,0018 dan debt ratio tertinggi mencapai 0,6858 .

Variabel kualitas audit yang diproksi dengan kualifikasi auditor sebagai big 4 atau non big 4.

Tabel 4

Kualitas Auditor

\begin{tabular}{|l|c|c|}
\hline Kualitas Auditor & $\begin{array}{c}\text { Jumlah } \\
\text { emiten }\end{array}$ & Persentase \\
\hline Non Big 4 & 54 & 49,1 \\
Big 4 & 56 & 50,9 \\
\hline Jumlah & $\mathbf{1 1 0}$ & $\mathbf{1 0 0 , 0}$ \\
\hline
\end{tabular}

Sumber : Data sekunder yang diolah

Hasil pengamatan dari 110 laporan keuangan dari perusahaan sampel selama tahun 2006 hingga 2008 diperoleh bahwa 54 laporan atau 49,1\% dilakukan oleh KAP Non Big 4, sedangkan 56 laporan keuangan diaudit oleh KAP yang termasuk dalam Big 4.

\section{HASIL DAN PEMBAHASAN Hasil Analisis}

Untuk menguji hipotesis akan digunakan analisis regresi linier berganda. Pengolahan data dilakukan dengan menggunakan batuan program SPSS. Hasil yang diperoleh selanjutnya akan diuji kemaknaan model tersebut secara simultan dan secara parsial : 


\section{a. Hasil Uji Persamaan Regresi}

Hasil pengujian persamaan regresi tersebut dapat dijelaskan sebagai berikut :

Tobins $Q=1,270-0,708$ INED $-0,020$ INSIDER + 0,006 FOREIGN + 0,667 DEBT $+0,465$ AUDIT

Model regresi tersebut memberikan koefisien proporsi komisaris independent (INED) dan INSIDER dengan arah negative sedangkan pada variabel FOREIGN, DEBT dan AUDIT mendapatkan koefisien regresi dengan arah positif. Hal ini berarti bahwa variabel INED dan INSIDER saja yang memiliki arah pengaruh yang tidak sama dengan apa yang diharapkan sebagaimana dalam hipotesis.

\section{b. Hasil Uji F}

Pengujian hipotesis uji $\mathrm{F}$ digunakan untuk melihat apakah secara keseluruhan variabel bebas mempunyai pengaruh yang bermakna terhadap variabel terikat. Dari hasil pengujian simultan diperoleh sebagai berikut :

Tabel 5

Hasil Uji F

ANOVA

\begin{tabular}{|c|c|c|c|c|c|c|}
\hline Model & & $\begin{array}{r}\text { Sum of } \\
\text { Squares }\end{array}$ & df & Mean Square & $\mathrm{F}$ & Sig. \\
\hline \multirow[t]{3}{*}{1} & Regression & 13.789 & 5 & 2.758 & 6.174 & $.000^{\circ}$ \\
\hline & Residual & 46.452 & 104 & .447 & & \\
\hline & Total & 60.241 & 109 & & & \\
\hline
\end{tabular}

Hasil pengolahan data terlihat bahwa nilai $\mathrm{F}=6,174$ dengan probabilitas sebesar $0,000<0,05$. Nilai probabilitas yang lebih kecil dari 0,05 menunjukkan bahwa nilai perusahaan Tobins Q dapat dijelaskan dengan GCG.

\section{c. Koefisien Determinasi}

Hasil nilai adjusted $R$-Square dari regresi digunakan untuk mengetahui besarnya nilai perusahaan yang dipengaruhi oleh variabel-variabel bebasnya.

Tabel 6

Koefisien Determinasi

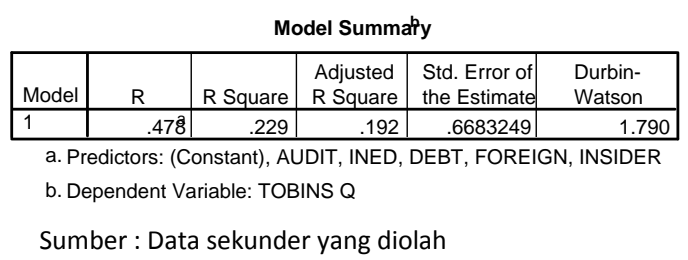

Pada tabel 6 menunjukkan bahwa bahwa koefisien determinasi yang ditunjukkan dari nilai adjusted $R^{2}$ sebesar 0,192 . Hal ini berarti bahwa $19,2 \%$ variasi nilai perusahaan dijelaskan oleh INED, INSIDER, FOREIGN, DEBT dan AUDIT, sedangkan sisanya sebesar $80,8 \%$ nilai perusahaan dapat dijelaskan oleh variabel lainnya.

\section{Pembahasan}

Hasil analisis dalam penelitian ini menunjukkan bahwa kinerja saham perusahaan (Tobin's $Q$ ), dapat dijelaskan oleh kombinasi penggunaan variabel komposisi komisaris independen (INED), kepemilikan manajerial (INSIDER), kepemilikan asing (FOREIGN), hutang (DEBT) dan kualitas audit. (AUDIT), yang ditunjukkan pada tabel 4.1. Secara parsial ada empat variable yang berpengaruh secara signifikan terhadap kinerja saham perusahaan yaitu kepemilikan manajerial, kepemilikan asing, hutang serta fee audit. Secara keseluruhan hasil hipótesis dengan menggunakan regresi dapat dilihat pada tabel 7 berikut ini :

Tabel 7. Ringkasan Hasil Hipotesis

\begin{tabular}{|c|l|c|}
\hline KODE & \multicolumn{1}{|c|}{ HIPOTESIS } & HASIL \\
\hline H1 & $\begin{array}{l}\text { Komposisi komisaris } \\
\text { independent (INED) tidak } \\
\text { memiliki pengaruh yang } \\
\text { signifikan terhadap nilai } \\
\text { kinerja saham perusahaan } \\
\text { (Tobin's Q) }\end{array}$ & Ditolak \\
\hline H2 & $\begin{array}{l}\text { Kepemilikan manajerial } \\
\text { (INSIDER) memiliki tidak } \\
\text { pengaruh positif dan } \\
\text { signifikan terhadap kinerja } \\
\text { saham perusahaan }\end{array}$ & Ditolak \\
\hline H3 & $\begin{array}{l}\text { Kepemilikan saham asing } \\
\text { (FOREIGN) memiliki } \\
\text { pengaruh positif dan } \\
\text { signifikan terhadap kinerja } \\
\text { saham perusahaan }\end{array}$ & Diterima \\
\hline H4 & $\begin{array}{l}\text { Hutang memiliki pengaruh } \\
\text { positif dan signifikan } \\
\text { terhadap kinerja saham } \\
\text { perusahaan }\end{array}$ & Diterima \\
\hline H5 & $\begin{array}{l}\text { Kualitas audit memiliki } \\
\text { pengaruh positif dan } \\
\text { signifikan terhadap kinerja } \\
\text { saham perusahaan }\end{array}$ & Diterima \\
\hline
\end{tabular}




\section{Pengaruh Komposisi Komisaris Independen terhadap Kinerja Saham Perusahaan}

Berdasarkandari hasil analisis regresi menunjukkan bahwa komposisi komisaris independen tidak berpengaruh secara signifikan terhadap kinerja saham perusahaan. Dari 110 perusahaan yang dijadikan obyek penelitian menunjukkan bahwa ratarata proporsi jumlah komisaris independen dibanding dengan total komisaris diperoleh rata-rata sebesar 0,3671. Hal ini berarti bahwa secara rata-rata, perusahaan obyek penelitian mempunyai $\quad 36,71 \% \quad$ komisaris independen.

Hasil penelitian ini, yang menghubungkan antara komposisi komisaris indepeden terhadap kinerja saham perusahaan menunjukkan hasil yang konsisten dengan penelitian yang dilakukan oleh Hermalin dan Weisbach, (1991), yang menemukan bukti bahwa non executive director (NED) tidak berpengaruh terhadap kinerja saham perusahaan. Hal ini disebabkan adanya persentase rata-rata dari komisaris independen dari obyek penelitian yang sebesar $36,71 \%$, tidak dianggap investor mampu untuk mengkontrol direktur dalam menjalankan perusahaan. Berdasarkan informasi tersebut bisa dikatakan bahwa jumlah dari komposisi komisaris independen tidak menjadi sinyal bagi investor dalam menentukan investasinya.

\section{Pengaruh Kepemilikan Manajerial terhadap Kinerja Saham Perusahaan}

Berdasarkan dari hasil analisis regresi menunjukkan bahwa kepemilikan manajerial berpengaruh positif signifikan terhadap kinerja saham perusahaan. Dari 110 perusahaan yang dijadikan obyek peneitian menunjukkan rata-rata kepemilikan manajerial sebesar 0,7963. Hal ini berarti bahwa 79,63\% saham perusahaan dimiliki oleh orang dalam perusahaan. Sehingga memungkinkan dapat memperkecil masalah keagenan.

\section{Pengaruh Kepemilikan Asing terhadap Kinerja Saham Perusahaan}

Berdasarkan dari hasil analisis regresi menunjukkan bahwa kepemilikan asing berpengaruh positif signifikan terhadap kinerja saham perusahaan. Dari 110 perusahaan yang dijadikan obyek peneitian menunjukkan rata-rata kepemilikan asing sebesar 23,04\%.. Hal ini berarti bahwa $23,04 \%$ saham perusahaan dimiliki oleh orang asing. Sehingga memungkinkan dapat mengupgrade perusahaan melalui impor langsung modal baru dan teknologi.

\section{Pengaruh Hutang terhadap Kinerja Saham Perusahaan}

Berdasarkan dari hasil analisis regresi menunjukkan bahwa Hutang berpengaruh positif signifikan terhadap kinerja saham perusahaan. Dari 110 perusahaan yang dijadikan obyek peneitian menunjukkan rata-rata hutang perusahaan sebesar 0,2547. Hal ini berarti bahwa $25,47 \%$ aset yang digunakan perusahaan berasal dari hutang jangka panjang perusahaan. Jumlah ini cukup besar, sehingga memungkinkan untuk mengatakan bahwa sebagian besar perusahaan telah mendapatkan kelayakan dalam memperoleh kredit dari perbankan.

\section{Pengaruh Kualitas Audit terhadap Kinerja Saham Perusahaan}


Berdasarkan dari hasil analisis regresi menunjukkan bahwa kualitas berpengaruh positif signifikan terhadap kinerja saham perusahaan. Dari 110 perusahaan yang dijadikan obyek penelitian menunjukkan rata-rata kualitas audit perusahaan sebesar 0,15488 . Hal ini berarti bahwa $15 \%$ perusahaan diaudit oleh perusahaan big four. Jumlah ini cukup besar, sehingga memungkinkan untuk mengatakan bahwa sebagian besar perusahaan telah melakukan upaya untuk dinilai oleh pihak independent yang kredibel.

\section{SIMPULAN}

Berdasarkan hasil analisis dan pengujian, maka diperoleh kesimpulan sebagai berikut :

1. Hasil analisis data menunjukkan tidak adanya pengaruh yang signifikan antara komisaris independent (INED) terhadap kinerja perusahaan, hal ini membuktikan bahwa tidak adanya pengaruh komisaris independent terhadap kinerja saham. Temuan tersebut mengindikasikan bahwa semakin rendah jumlah komisaris independen maka bisa menyebabkan turunnya nilai perusahaan di mata investor.

2. Hasil analisis data menunjukkan adanya pengaruh positif antara kepemilikan manajerial terhadap kinerja perusahaan, yang berarti bahwa semakin besar jumlah kepemilikan manajerial akan meningkatkan nilai perusahaan. Temuan tersebut mengindikasikan bahwa semakin besar jumlah kepemilikan manajerial maka akan dijadikan para investor sebagai nilai tambah perusahaan yang dianggap bisa menekan adanya potensi agensi.

3. Hasil analisis data menunjukkan bahwa terdapat pengaruh positif signifikan antara kepemilikan asing terhadap kinerja perusahaan. Hal ini mengindikasikan bahwa para investor di Bursa Efek Indonesia ternyata juga memperhatikan jumlah kepemilikan asing dalam menilai suatu perusahaan.

4. Hasil analisis data menunjukkan bahwa terdapat pengaruh positif signifikan antara hutang dengan nilai perusahaan. Hal ini juga mengindikasikan bahwa para investor di Bursa Efek Indonesia memperhatikan pengawas lain akan suatu perusahaan.

5. Hasil analisis data menunjukkan bahwa terdapat pengaruh positif signifikan antara kualitas audit dengan nilai perusahaan. Hal ini mengindikasikan bahwa kualitas audit yang digambarkan dengan kantor akuntan yang termasuk big 4 akan berpengaruh terhadap nilai suatu perusahaan. Kualitas audit biasanya mempengaruhi luasnya suatu pemeriksaan sehingga kredibilitas hasil audit bisa diandalkan.

\section{Keterbatasan}

Sejumlah keterbatasan yang ada dalam analisis ini, yang memungkinkan dapat menimbulkan 
gangguan pada hasil analisis ini adalah sebagai berikut :

1. Sampel yang terbatas dengan perusahaan yang menerbitkan laporan keuangan, dan didalamnya terdapat akun persediaan yang berhubungan dengan penilaian perusahaan dengan menggunakan rasio yaitu Tobin's Q, sehingga mengeluarkan perusahaan perbankan.

2. Pengujian yang menghasilkan adjusted $R^{2}$ sebesar 0,192, sehingga ada beberapa variabel lain yang diduga berpengaruh terhadap nilai perusahaan.

\section{Implikasi}

Penelitian ini memiliki beberapa implikasi sebagai berikut :

1. Secara teoritis penelitian ini memberikan kontribusi pada literature - literature terutama yang banyak mengamati hubungan antara faktor - faktor corporate governance dengan nilai perusahaan.

2. Secara praktik penelitian ini memberikan kontribusi pada para pelaku pasar bahwa sebetulnya untuk menilai suatu perusahaan dalam menentukan investasinya, para investor mungkin bisa berpedoman pada konsep penelitian

\section{Saran}

Saran untuk pengembangan penelitian ini adalah :

1. Penelitian ini hanya berdasarkan data yang relatif pendek yaitu selama 3 tahun (2006 - 2008) atas perusahaan LQ'45 di Bursa Efek Indonesia. Untuk penelitian selanjutnya akan lebih baik jika dilakukan dengan memperpanjang waktu penelitian.

2. Penelitian ini menghubungan antara faktor - faktor corporate governance dengan nilai perusahaan yang dilakukan dalam periode waktu pengamatan yang sama, sehingga dimungkinkan akan lebih baik, jikalau nilai perusahaan itu diamati dengan menggunakan tahun sesudah pengamatan faktor corporate governance.

\section{DAFTAR PUSTAKA}

Benfratello L. and Sembenelli, A. (2002), "Foreign ownership and productivity; is the direction of causality so obvious?", Paper presented at the CEPR/LdA Workshop on Labour Market effect of European Foreign Investment, available at: www.ssrn.com.

Bushman, R., Chen, Q., Engel, E. And Smith, A (2004).'Financial accounting information, organizational complexity and corporate governance systems", Journal of Accounting and Economics, Vol. 37. pp.167201.

Darmawati, Deni, Khomsiyah, Rika Gelar R. 2004 Hubungan Corporate Governance dan Kinerja Perusahaan. Simposium Nasional akuntansi VII Denpasar 2-3 Desember 2004.

Daily CM. and Dalon, DR (1994), "Corporate governance and the bankrupt firm; an empirical assessment", 
Strategic Management

Journal, Vol. 15 No. 6, pp. 643-56

DeAngelo, LE., (1981), "Auditor size and audit quality", Journal of Accounting and Economics, Vol. 3, pp. 183-99.

Defond, M. and Jiambalvo J. (1993), "Factors related to auditor client disagreement over income-increasing accounting methods", Contemporary Accounting Research, Vol. 9, pp 415-31.

Fama EF. And Jensen MC (1983), "Separation of ownership and control", Journal of Law and Economics, Vol. 26 No. 2, pp. 301-28.

Ferguson, A., Lennox, C. and Taylor, S (2005),"Audit fee adjustment in the presence of nominal rigidities; evidence and explanations", Working paper sponsored by capital markets Co-operative Research Centre (CMCRC Ltd.), Australia, available at : www.accg.mq.edu.au /html/seminar/s2_papers/ staylor_s2_2005.pdf

Francise, J., Kurana, I., and Pereira, R. (2003),'The role of accounting and auditing in corporate governance and the development of financial market around the world', Asia Pacific Journal of Accounting and Economics, Vol.10, pp. 1-31.

Francise JR., and Simon, D, (1987) “A test of audit pricing in smallclient of the US audit market', The Accounting Review, Vol. 62 No. 1, pp. 145-57

Giner, B. 1997, "The influence of company characteristics and accounting regulation on information disclosed by Spanish firms', European Accounting Review, Vol. 6, No. 1, pp. 45-68.

Hermalin BE., and Weisbach, MS., (1991), "The effects of board composition and direct incentives on firm performance ", Financial Management, Winter, pp. 101-12.

Harvey, CR., Liechty, JC., Liechty, MW. And Muller, P. (2003),"Portfolio selection with higher moments", working paper, Drexel University, Philadelphia, PA.

Himmelberg, CP. Hubbard, RG and Palia D. (1999), "Understanding the determinants of managerial ownership and the link between ownership and performance", Journal of Financial Economics, Vol. 53, pp. 353-84.

Hingaroni, A. Lehn, K. and Makhija, A. (1997), "Investor behaviour in mass privatisation: the case of the Czech Voucher Scheme", Journal of Financal Economics, Vol. 44, pp. 34996.

Jensen M.C. and Meckling W. H. (1976), "Theory of the firm : managerial behaviour, agency costs and ownership structure" Journal of Financial Economics, Vol. 3, pp. 303-60.

Khanna, A., Mahentiran., S. and Curci R. (2005) “ Managerial ownership and firm value agency problem of empire building and overvalued 
equity", unpublished working paper, University of Butler, Indianapolis, IN.

Komite Nasional Kebijakan Corporate Governance (KNKCG). 2001. Pedoman Good Corporate Governance. www.kncg.go.id

Kozlov, YK. Melentieva, N. and Ponomareva, N. (2002),"Does foreign ownership matter?", working papper, available at : www.ssrn.com/paper.taf?abstrac $\underline{\mathrm{t} \text { id }}=257081$.

Lang, L., Stulz, R., and Walkling, R. (1989)," Managerial performance, Tobin's Q and the gains from successful tender offers", Journal of Financial Economics, Vol. 24. p. 138.

Lindenberg, E and Ross, S. (1981) "Tobin's Q ratio and industrial organisations', Journal of Business, Vol.. 54, p. 12.

Lastanti, Hexana Sri. 2005. Hubungan Struktur Corporate Governance dengan Kinerja Perusahaan dan Reaksi Pasar. Proceeding Konferensi Nasional Akuntansi: Peran Akuntan dalam Membangun Good Corporate Governance. Fakultas Ekonomi Trisakti Jakarta.

Lindenberg, E., and Ross, S. (1981),"Tobin"s Q ratio and industrial organizations", Journal of Busniess, Vol. 54, p. 12.

Mangel, R, and Singh, H. (1993), “ Ownership structure as a determinant of share value, evidence from newly privatized Czech firm”, Financial Review, Vol. 35, pp. $1-32$.
Mitton T, (2002), “A cross firm analysis of the impact of corporate governance on the East Asian financial crisis', Journal of Finacial Econmics, Vol. 64 No. 2, pp.215-41.

Mohd Hasan Che Hat, Rashidah Abdul Rahman and Sakthi Mahentiran, “ Corporate Governance, Transparency and Performan of Malaysian Companies" Managerial Auditing Journal Vol. 22 No. 8 2008

Morris, RD.1987. "Signalling, Agency Theory and Accounting Policy Choice", Accounting and Business Research, Vol. 18. No. 69 pp. 47-56.

Pearce JA. And Zahra, SA. (1992). "Board composition from a strategic perspective'. Strategic Management Journal, Vol. 29 No.4.

Riyanto, Bambang. 2005. Corporate Goveranance: Isu Utama penelitian. Kompak. No 2. Hal 163-171.

Sabeni, A. 2002. An Empirical Analysis of the Relation between the BOD Composition and the Level of Voluntary Disclosure. Simposium Nasional Akuntansi $V$.

Sabeni, A. 2003. The Relationship Between Corporate Governance Structure and The Level of Voluntary Disclosure. Jurnal Bisnis Strategi. Vol 12/Desember/Th VIII/2003. Hal 19-29.

Sabeni, A. 2005. Peran Akuntan Dalam Menegakkan Prinsip Good Corporate Governance (Tinjauan Perspektif Agency Theory). Pidato Pengukuhan Guru Besar. Fakultas 
Ekonomi Universitas

Diponegoro. Semarang

Shapiro, C. (1983),'Premiums for high quality products as returns to reputations", Quarterly Journal of Economics, Vol. 97, pp.659-79.

Shleifer, A. and Vishny, RW. (1987), "A survey of corporate governance", The Journal of Finance, Vol. I - II No. 2, pp. 737-83.

Sukamulja, Sukmawati. 2004. Good Corporate Governance di Sektor Keuangan: Dampak GCG Terhadap Kinerja Perusahaan (Kasus di Bursa Efek Jakarta). BENEFIT. Vol 8, No, 1, Juni 2004. Hal 1-25.

Sulistiyanto, Sri dan Meniek S Prapti. 2003. Good Corporate Governance: Bisakah Meningkatkan Kepercayaan Masyarakat? Ekobis. Vol 4 No 1. Januari 2003. Hal 8393.

Surata, Eddy dan Pranata P Midiastuty. 2005. Pengaruh Good Corporate Governance Terhadap Praktek Manajemen Laba. Proceeding Konferensi Nasional Akuntansi: Peran Akuntan dalam Membangun Good Corporate Governance. Fakultas Ekonomi Trisakti Jakarta.

Venkataraman, R. Weber J., and Willenborg. M. (2005), "Litigation risk, audit fees and audit quality; initial public offering as a natural experiment", paper presented at the 2004 American Accountants Association (AAA), Annual Meeting.
Wahidahwati, 2002, “ Pengaruh Kepemilikan Manajerial \& Kepemilikan Institusional Pada Kebijakan Hutang Perusahaan : Sebuah Perspektif Theory Agency ", Jurnal riset Akuntansi Indonesia, Vol 5, No. 1, hal 1-16.

Weir, C., Laing, D., and McKnight, PJ., (2002),'Internal and external governance mechanisms: their impact on the performance of large UK public companies", Journal of Business Finance \& Accounting, Vol. 29, No. 5/6, pp. 579-661.

Wright, DW. (1996), "Evidence on relation between corporate governance characteristics and the quality of financial reporting", Available at; http://ssrn.com/abstract . 